Yu. B. Belousova, S. N. Kozlova. Smolensk: «MAKMAKh»; 2007.

14. Ratsionalnaya antimikrobnaya terapiya. Pod red. S. V. Yakovleva. 2-e izd., pererab. i dop. M.: «Litterra»; 2015.

15. Sengupta D., Leontiadou H., Mark A. E., Marrink S. J. Toroidal pores formed by antimicrobial peptides show significant disorder. Biochim. Biophys. Acta Biomembr. 2008;1778(10):2308-2317. doi: 10.1016/j. bbamem.2008.06.007
16. Sullivan C. J., Venkataraman S., Retterer S. T., Allison D. P., Doktycz M. J. Comparison of the indentation and elasticity of $\mathrm{E}$. coli and its spheroplasts by AFM. Ultramicroscopy. 2007;107(10-11):934-942. doi: 10.1016/j.ultramic.2007.04.017

17. Wang G. Human Antimicrobial Peptides and Proteins. Pharmaceuticals. 2014;7(5):545-594. doi: 10.3390/ ph7050545

About authors:

Baturin Vladimir Aleksandrovich, MD, PhD, Professor, Head of the Department of Clinical Pharmacology;

tel.: +78652713466, e-mail: prof.baturin@gmail.com

Selimov Magomed Aslanovich, PhD, senior researcher of scientific laboratory «Nanobiotechnology and biophysics»;

tel.: +79288200432; e-mail: selimovma@mail.ru

Bolatchiev Albert Dobaevich, PhD-student of the Department of Clinical Pharmacology; tel.: +79288205551; e-mail: bolatalbert@gmail.com Sadovoy Vladimir Vsevolodovich, Doctor of Technical Sciences, Professor of the Department of Food Technology and Commodity Science; e-mail: vsadovoy@yandex.ru

Budkevich Roman Olegovich, Ph.D., Associate Professor, Head of the laboratory «Nanobiotechnology and biophysics»; tel.: +79624452091; e-mail: budkev@mail.ru

Baturina Maria Vladimirovna, MD, Associate Professor of the Department of Clinical Pharmacology; tel.: +78652713466; e-mail: nimdark@mail.ru

(C) Group of authors, 2017

UDC 543.544-543.42:615,15

DOI - https://doi.org/10.14300/mnnc.2017.12088

ISSN - 2073-8137

\title{
METHIDICAL APPROACHES TO BIOASSAY OF PHENOLIC HYDROXYLENES CONTAIN SUBSTANCES
}

\author{
Khokhlov A. L. 1, Yaichkov I. I. ${ }^{2}$, Dzhurko Yu. A. ${ }^{3}$, Shitov L. N. 1, 3 \\ 1 Yaroslavl State Medical University, Russian Federation \\ 2 Center of Transfer of Pharmaceutical Technologies named after M. V. Dorogov, \\ Yaroslavl, Russian Federation \\ 3 "Quinta-Ánalytica Yaroslavl» LLC, Russian Federation
}

\section{МЕТОАИЧЕСКИЙ ПОАХОА К АНААИЗУ ВЕЩЕСТВ, СОАЕРЖАЩИХ В СТРУКТУРЕ ФЕНОАЬНЫЕ ГИАРОКСИАЫ, ПРИ БИОАНААИТИЧЕСКИХ ИССАЕАОВАНИЯХ}

\author{
А. А. Хох^ов ${ }^{1}$, И. И. Яичков ${ }^{1,2}$, Ю. А. Ажурко ${ }^{3}$, А. Н. Шитов ${ }^{1,3}$ \\ 1 Ярославский госуАарственный МеАицинский университет, Россия \\ 2 Центр трансфера фармацевтических технологий им. М. В. Аорогова, \\ ярославль, Россия \\ 3 ООО «Квинта-Аналитика Ярослав^ь», Россия
}

This article describes method of development approaches for bioassay of substances containing stable and unstable phenolic hydroxyls using methyldopa and mycophenolic acid for example

Keywords: phenolic hydroxyls, bioassay, mycophenolic acid, methyldopa, stabilization

Описаны подходы к разработке биоаналитических методик для определения веществ, содержащих стабильные и нестабильные фенольные гидроксилы, на примере метилдопы и микофеноловой кислоты.

Ключевые слова: фенольные гидроксилы, биоаналитика, микофеноловая кислота, метилдопа, стабилизация

$\mathbf{T}$

he main step of bioequivalence and pharmacokinetic studies is a determination drug substance of concentration in biological fluids, such as plasma, serum and whole blood. Some substances are able to significantly decompose during the storage of samples. Are drugs, containing phenolic hydroxyls. Examples of the substances. The oxidation ability of phenols directly depends from the amount of phenolic hydroxyls in one benzene ring [2]. Mycophenolic acid (MPA) (Fig. 1 A) and methyldopa (MD) (Fig. 1 B) which contains one and two phenolic hydroxyls, respectively, were selected to work out approaches development of bioanalytical methods of the quantitative determination of drugs, containing phenolic hydroxyls. 
<smiles>COc1c(C)c2c(c(O)c1C/C=C(\C)CCC(=O)O)C(=O)OC2</smiles>

A<smiles>CC(N)(Cc1ccc(O)c(O)c1)C(=O)O</smiles>

B

Fig. 1. Structures of mycophenolic acid (A) and methyldopa (B)

Detection of mycophenolic acid was carried out in SIM negative ions mode by the molecular ion with $319 \mathrm{~m} / \mathrm{z}$.

Results and Discussion. The preliminary stability study of mycophenolic acid was carried out in plasma samples at the concentration of $25 \mu \mathrm{g} / \mathrm{ml}$ using different anticoagulants $\left(\mathrm{K}_{3} \mathrm{EDTA}\right.$ and heparin). The calculation of

The results of publication showed that addition of antioxidant solutions to biological fluids samples is not necessary for quantification of both substances $[5-9,11-17$, 19-22]. There is potential risk of methyldopa oxidation due to two phenolic hydroxyls in the structure. It is known that $10 \%$ sodium metabisulphite solution is required for stabilization of dopamine in human plasma [18]. Dopamine is similar to the structure of methyldopa. Addition of $10 \%$ ascorbic acid solution is necessary to prevent degradation of catechins (polyphenolic compounds) and 3,4-dihydroxycinnamic acid (diatomic phenolic compound) in urine samples.

The aim of study was to develop of the methodological and approaches to bioassay of substances, containing phenolic hydroxyls in the structure.

Material and Methods. The quantitative determination of methyldopa was performed on a Shimadzu HPLCMS/MS system equipped with two LC-20AD pumps, an SIL-20AC autosampler, a STO-20AC column thermostat with an integrated 6-port valve and a triple quadrupole mass spectrometer detector LCMS-8050.

Protein precipitation was used for sample preparation of plasma containing MD. An aliquot $400 \mu \mathrm{l}$ of a deuterated internal standard MD (MD-D3) methanol solution were added to $100 \mu \mathrm{l}$ of plasma. The mixture was vortexed and centrifuged for $10 \mathrm{~min}$ at $3500 \mathrm{rpm}$ and a temperature of $+4{ }^{\circ} \mathrm{C}$. The supernatant was injected into the chromatographic system. The separation of the sample components was performed using two chromatographic columns Phenomenex Luna Phenyl-Hexyl $(50 \times 3.0 \mathrm{~mm}, 5 \mu \mathrm{m})$ and Phenomenex Synergi Fusion RP $80 \AA$ ( $150 \times 3.0 \mathrm{~mm}, 4 \mu \mathrm{m})$. The mixture of methanol, water and an aqueous solution of ammonium formate in a concentration of $80 \mathrm{mmol} / \mathrm{I}$ were used as the mobile phase $(40: 40: 20 \mathrm{v} / \mathrm{v})$. Mass spectrometric detection was carried out in positive ion mode using electrospray ionization. The MRM-transitions $212 \rightarrow 139 \mathrm{~m} / \mathrm{z}$ was selected for MD; $215 \rightarrow 169 \mathrm{~m} / \mathrm{z}$ for MD-D3.

The Agilent 1260 Infinity HPLC-MS system for quantify of mycophenolic acid consisted of G1311C pump, the G1329B ALS autosampler, the G1316A column thermostat and the 6130 Single quadrupole mass spectrometer equipped with JetStream electrospray ion source.

Sample preparation was also performed using protein precipitation: an aliquot of $50 \mu \mathrm{l}$ plasma was mixed and vortexed with $200 \mu \mathrm{l}$ methanol. The mixture was centrifuged for 5 minat $10000 \mathrm{rpm}$. $5 \mu \mathrm{l}$ of the supernatant was processed to a LC/MS determination. The chromatographic separation was performed using Agilent Zorbax Eclipse Plus C18 column $(100 \star 4.6 \mathrm{~mm}, 3.5 \mu \mathrm{m})$ with isocratic elution of the mobile phase composed of acetonitrile, water and $0.1 \%$ solution of formic acid $(50: 45: 5 \mathrm{v} / \mathrm{v})$ at a flow rate $0.4 \mathrm{ml} /$ min and oven temperature $40{ }^{\circ} \mathrm{C}$. the MPA concentration at this step was performed using the external standard method. The results obtained after 24 hours storage of samples at room temperature and 3 freeze/thaw cycles meet the acceptance criteria: the mean MPA concentrations were $95.2 \%$ and $102.1 \%$ of the theoretical concentration, respectively. Therefore, this analyte is stable, and addition of antioxidant is not required. However, the main metabolite of MPA is the phenolic glucuronide (MPAG). Its plasma concentrations can reach $100 \mu \mathrm{g} / \mathrm{ml}$ [9]. The back conversion during storage of this compound has been insufficiently studied: a number of publications indicate the necessity of using the buffer solutions to prevent this phenomenon $[5,6]$. Some studies indicate that hydrolysis of MPAG is not significant, and the addition of stabilizers is not required [4, 11]. However, back conversion of MPAG was not investigated in the majority of researches $[7,8,13,15,20-22]$.

Aliquots of $50 \mu \mathrm{l}$ of samples containing a metabolite at a concentration of $100 \mu \mathrm{g} / \mathrm{ml}$, were taken at a certain storage time at room temperature, and the MPA peak areas of this samples were compared with the peak area of the MPA samples at the concentration of LLOQ level (Table 1) during evaluation of back conversion.

The level of back conversion was within the acceptable limits (less than $20 \%$ of the peak area of the LLOQ samples) for 6 hours using anticoagulant $\mathrm{K}_{3}$ EDTA. It is much longer than in the heparin samples. Plasma stabilizing heparin can be stored at room temperature for no longer than $1 \mathrm{~h}$. Therefore, plasma with the addition of $\mathrm{K}_{3}$ EDTA was used for validation tests.

The preliminary evaluation of short-term stability and freeze/thaw stability of methyldopa was carried out on plasma samples at the concentration level of $2.40 \mu \mathrm{g} / \mathrm{ml}$ using $\mathrm{K}_{3}$ EDTA and heparin as anticoagulants by comparing the ratios of peak areas «analyte/internal standard» obtained before and after investigation. MD underwent significant oxidative degradation during application of both anticoagulants (Table 2). Therefore, addition of antioxidant is necessary to prevent oxidation of MD in plasma.

Table 1 Study of Back conversion of phenolic glucuronide of mycophenolic acid

\begin{tabular}{|c|c|c|c|c|c|c|c|c|c|}
\hline & \multicolumn{9}{|c|}{$\mathrm{K}_{3}$ EDTA } \\
\hline & $\begin{array}{c}\text { Mean } \\
\text { peak } \\
\text { area of } \\
\text { LLOQ } \\
\text { sample }\end{array}$ & Initial & $1 \mathrm{~h}$ & $2 \mathrm{~h}$ & $3 \mathrm{~h}$ & $4 \mathrm{~h}$ & $6 \mathrm{~h}$ & $8 \mathrm{~h}$ & $24 \mathrm{~h}$ \\
\hline $\begin{array}{l}\text { Peak area } \\
\text { of MPA }\end{array}$ & 8073.5 & 0 & 339.6 & 485.3 & 520.4 & 1077.8 & 1374.7 & 1801.0 & 3632.7 \\
\hline $\begin{array}{l}\text { \% of the } \\
\text { peak area } \\
\text { of LLOQ } \\
\text { sample }\end{array}$ & - & 0 & 4.2 & 6.0 & 6.4 & 13.3 & 17.0 & 22.3 & 45.2 \\
\hline \multicolumn{10}{|c|}{ Heparin } \\
\hline $\begin{array}{l}\text { Peak area } \\
\text { of MPA }\end{array}$ & 6512.0 & 523.0 & 1204.2 & 1556.0 & 3568.5 & 4899.0 & 7851.4 & 10045.0 & 523.0 \\
\hline $\begin{array}{l}\text { \% of the } \\
\text { peak area } \\
\text { of LLOQ } \\
\text { sample }\end{array}$ & - & 8.0 & 18.5 & 23.9 & 54.8 & 75.2 & 120.6 & 154.3 & 8.0 \\
\hline
\end{tabular}


The selection of stabilizers to prevent oxidation of methyldopa

\begin{tabular}{|c|c|c|c|}
\hline Stabilizer & $\begin{array}{l}\text { Concentration } \\
\text { of stabilizer, \% }\end{array}$ & $\begin{array}{c}\text { Short-term } \\
\text { stability }(24 \mathrm{~h} \\
\text { at room tem- } \\
\text { perature), \% } \\
\text { of initial con- } \\
\text { centration } \\
n=2\end{array}$ & $\begin{array}{c}\text { Freeze } \\
\text { and thaw } \\
\text { stabil- } \\
\text { ity, \% of } \\
\text { initial con- } \\
\text { centration } \\
n=2 \\
\end{array}$ \\
\hline \multicolumn{4}{|c|}{$\mathrm{K}_{3}$ EDTA } \\
\hline $\begin{array}{l}\text { Without } \\
\text { stabilizer }\end{array}$ & - & 30.29 & 80.04 \\
\hline \multirow{2}{*}{ Ascorbic acid } & 5 & 88.44 & 102.30 \\
\hline & 10 & 94.91 & 96.17 \\
\hline $\begin{array}{l}\text { A mixture of } \\
\text { ascorbic acid, } \\
\text { sodium bicar- } \\
\text { bonate, so- } \\
\text { dium sulphite }\end{array}$ & $\begin{array}{l}5 \% \% \text { ascor- } \\
\text { bic acid, } 0.2 \% \\
\text { sodium sulphite, } \\
2.4 \% \text { sodium hy- } \\
\text { drogencarbonate }\end{array}$ & 89.31 & 98.24 \\
\hline \multirow{2}{*}{$\begin{array}{l}\text { Sodium } \\
\text { thiosulfate }\end{array}$} & 5 & 45.65 & 101.86 \\
\hline & 10 & 31.32 & 99.81 \\
\hline \multirow{2}{*}{$\begin{array}{l}\text { Sodium } \\
\text { metabisulfite }\end{array}$} & 5 & 66.84 & 102.68 \\
\hline & 10 & 75.99 & 97.25 \\
\hline \multicolumn{4}{|c|}{ Heparin } \\
\hline $\begin{array}{l}\text { Without } \\
\text { stabilizer }\end{array}$ & - & 47.16 & 93.18 \\
\hline \multirow{2}{*}{ Ascorbic acid } & 5 & 80.91 & 99.69 \\
\hline & 10 & 78.76 & 93.21 \\
\hline $\begin{array}{l}\text { A mixture of } \\
\text { ascorbic acid, } \\
\text { sodium bicar- } \\
\text { bonate, so- } \\
\text { dium sulphite }\end{array}$ & $\begin{array}{l}5 \% \text { ascorbic acid, } \\
0.2 \% \text { sodium } \\
\text { sulphite, } 2.4 \% \\
\text { sodium hydrogen- } \\
\text { carbonate }\end{array}$ & 72.48 & 95.07 \\
\hline \multirow{2}{*}{$\begin{array}{l}\text { Sodium } \\
\text { thiosulfate }\end{array}$} & \begin{tabular}{|c|}
5 \\
\end{tabular} & 79.41 & 93.91 \\
\hline & 10 & 83.46 & 97.78 \\
\hline \multirow{2}{*}{$\begin{array}{l}\text { Sodium } \\
\text { metabisulfite }\end{array}$} & 5 & 75.79 & 90.70 \\
\hline & 10 & 73.22 & 88.70 \\
\hline
\end{tabular}

The selection of stabilizer and anticoagulant combination was performed by adding aqueous solutions of ascorbic acid, sodium sulfite, thiosulphate and metabisulphite in concentrations of 5 and $10 \%$, as well as a mixture of ascorbic acid, sodium sulfite, sodium hydroxycarbonate in the ratio of $0.2 \mathrm{ml}$ of antioxidant solution per $1 \mathrm{ml}$ of plasma. The concentration was also estimated by comparison of the peak area ratios «analyte/ internal standard» obtained before and after investigation.

Methyldopa was stable for $24 \mathrm{~h}$ at room temperature, and also during 3 freezethaw cycles after usage of ascorbic acid solutions in a concentration of 5 and $10 \%$ and a solution containing a mixture of ascorbic acid, sodium sulfite sodium hydrocarbonate in concentrations of $5 \%$, $0.2 \%$ and $2.4 \%$, respectively, in combination with $\mathrm{K}_{3}$ EDTA. The study of more concentrated ratios (1:2 or 1:1) was not carried out because the desired effect was achieved by addition antioxidant solutions to the plasma at a ratio of 1:5.

The mixture of ascorbic acid, sodium sulfite and sodium hydrocarbonate was selected for further method validation, because the area of the chromatographic peak of MD after their addition to the plasma was the highest (7756996, $n=6)$ in comparison with the peak areas after addition 5 and $10 \%$ ascorbic acid solutions (6465608 and 6720010 , respectively, $n=6$ ) to the plasma.

Deproteinizates of plasma samples containing solutions of sodium sulfite in methanol were converted into a viscous gel-like mass after $2 \mathrm{~h}$ of storage under autosampler conditions. It is prevented their injection into a chromatographic system. Therefore, the usage of this antioxidant is impossible. But the methanol deproteinizates retained its rheological properties after using sodium sulfite in low concentrations in combination with ascorbic acid and sodium hydrocarbonate (Fig. 2, 3).

The validation of the developed methods was conducted in accordance with the requirements of EMA Guideline [10], Guideline on the Evaluation of Medicinal Products [3], Decision of the Council of the Eurasian Economic Commission № 85 «On the Approval of the Rules for Conducting of Bioequivalence Studies on the of Medicinal Products in the Eurasian Economic Union» [11]. Validation tests for MD were performed with the addition of a solution of stabilizer to blank plasma. The results of validation tests meet to acceptance criteria (Table 3 ).

The results of validation tests of the developed methods

\begin{tabular}{|c|c|c|}
\hline Method & $\begin{array}{l}\text { Methyldopa } \\
\text { (HPLC-MS/MS) }\end{array}$ & $\begin{array}{l}\text { Mycophenolic acid } \\
\text { (HPLC-MS) }\end{array}$ \\
\hline Parameter & \multicolumn{2}{|l|}{ Results } \\
\hline & \multicolumn{2}{|c|}{$\begin{array}{l}\text { There was analysis of } 6 \text { samples of blank blood } \\
\text { plasma obtained from different sources and } \\
\text { plasma samples containing analytes at the } \\
\text { LLOQ concentration level }\end{array}$} \\
\hline Selectivity & $\begin{array}{l}\text { The interference in the } \\
\text { area of retention times of } \\
\text { MD did not exceed } 20 \% \text { of } \\
\text { the LLOQ level, and the in- } \\
\text { terference in the retention } \\
\text { times of MD-D3 did not ex- } \\
\text { ceed } 5 \% \text { of the mean chro- } \\
\text { matographic peak area }\end{array}$ & $\begin{array}{l}\text { The chromato- } \\
\text { grams did not } \\
\text { have any interfe- } \\
\text { rence at the } \\
\text { retention time } \\
\text { of MPA }\end{array}$ \\
\hline $\begin{array}{l}\text { Lower limit } \\
\text { of quan- } \\
\text { tification } \\
\text { (LLOQ) }\end{array}$ & $\begin{array}{l}0.02 \mu \mathrm{g} / \mathrm{ml} \text { (relative error } \\
+4.20 \% \text {, precision }\left(\mathrm{CV}^{*}\right) \\
-1.59 \% \text { ) }\end{array}$ & $\begin{array}{ll}0.05 \mu \mathrm{g} / \mathrm{ml} & \text { (rela- } \\
\text { tive error }-3.73 \% \text { \% } \\
\text { precision } \quad(\mathrm{CV}) \\
-1.59 \%)\end{array}$ \\
\hline Linearity & $\begin{array}{l}\text { The concentration range: } \\
0.02-3.00 \mu \mathrm{g} / \mathrm{ml} \text {. The } \\
\text { correlation coefficient } \\
\text { of the } 8 \text {-point calibration } \\
\text { curve }(r) \text { was ranged } \\
\text { from } 0.9977 \text { to } 0.9993\end{array}$ & $\begin{array}{l}\text { The concentration } \\
\text { range: } \\
0.05-30.00 \mu g / \\
\text { ml. The correla- } \\
\text { tion coefficient of } \\
\text { the } 8 \text {-point cali- } \\
\text { bration curve }(r) \\
\text { was ranged from } \\
0.9982 \text { to } 0.9985 \\
\end{array}$ \\
\hline $\begin{array}{l}\text { Precision } \\
\text { and accu- } \\
\text { racy }\end{array}$ & $\begin{array}{l}\text { Relative error was ranged } \\
\text { from }-5.28 \% \text { to }+7.42 \% \text {; } \\
\text { CV was ranged from } \\
0.69 \% \text { to } 3.97 \%\end{array}$ & $\begin{array}{l}\text { Relative error } \\
\text { was ranged } \\
\text { from }-14.02 \% \\
\text { to }+11.82 \% ; \\
C V \text { was ranged from } \\
0.37 \% \text { to } 6.76 \%\end{array}$ \\
\hline Recovery & $63.49 \%$ & $80.82 \%$ \\
\hline $\begin{array}{l}\text { Dilution } \\
\text { integrity }\end{array}$ & $\begin{array}{l}\text { Relative error: }+0.21 \% \\
(n=6), C V=1.78 \% \\
\text { (Twofold dilution of } \\
\text { samples with analyte } \\
\text { concentration } \\
\text { of } 4.80 \mu \mathrm{g} / \mathrm{ml} \text { ) }\end{array}$ & $\begin{array}{l}\text { Relative error: } \\
+3.82 \%(\mathrm{n}=6) \text {, } \\
\mathrm{CV}=6.27 \% \\
\text { (Twofold dilution of } \\
\text { samples with ana- } \\
\text { lyte concentration } \\
\text { of } 50.00 \mu \mathrm{g} / \mathrm{ml} \text { ) } \\
\end{array}$ \\
\hline $\begin{array}{l}\text { Matrix } \\
\text { effects }\end{array}$ & $\begin{array}{l}\text { NMF** was ranged from } \\
1.010 \text { to } 1.018 ; \\
\text { CV was ranged from } \\
0.40 \text { to } 1.27 \%\end{array}$ & $\begin{array}{l}\text { MF*** was ranged } \\
\text { from } 0.789 \text { to } \\
0.808 ; \mathrm{CV} \text { was } \\
\text { ranged } 2.96 \\
\text { to } 5.60 \% \\
\end{array}$ \\
\hline $\begin{array}{l}\text { Short- } \\
\text { term } \\
\text { stability } \\
(24 \mathrm{~h})\end{array}$ & $\begin{array}{l}95.50 \% \text { of the theoretical } \\
\text { concentration }\end{array}$ & $\begin{array}{l}99.46 \% \text { of the } \\
\text { theoretical } \\
\text { concentration }\end{array}$ \\
\hline 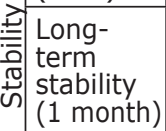 & $\begin{array}{l}90.74 \% \text { of the theoretical } \\
\text { concentration }\end{array}$ & $\begin{array}{l}100.38 \% \text { of the } \\
\text { theoretical } \\
\text { concentration }\end{array}$ \\
\hline \begin{tabular}{|c|} 
Freeze \\
and thaw \\
stability
\end{tabular} & $\begin{array}{l}104.43 \% \text { of the theoretical } \\
\text { concentration }\end{array}$ & $\begin{array}{l}103.55 \% \text { of the } \\
\text { theoretical } \\
\text { concentration }\end{array}$ \\
\hline
\end{tabular}

The note: ${ }^{*} \mathrm{CV}$ - coefficient of variation; ${ }^{* *} \mathrm{NMF}$ - normalized matrix factor; ${ }^{* \star *} \mathrm{MF}-$ matrix factor. 

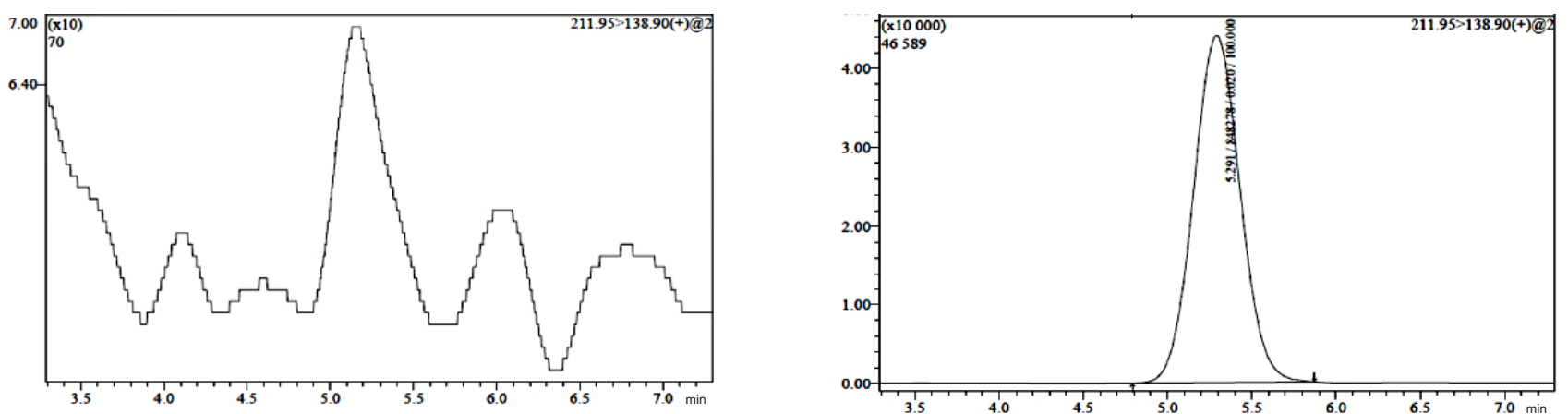

$M D-m / z-212 \rightarrow 139$
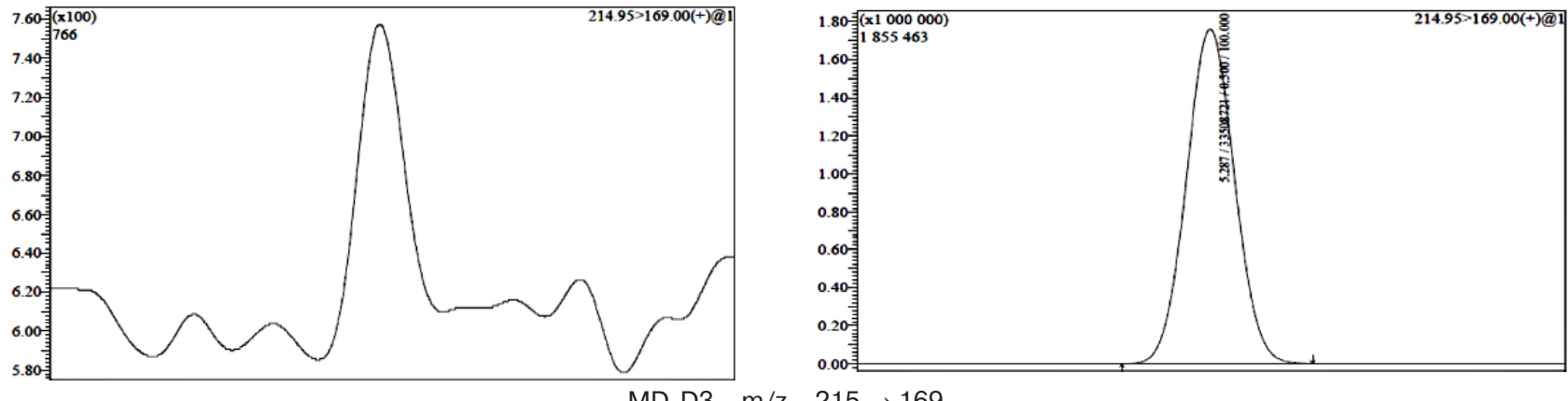

A

MD-D3 $-\mathrm{m} / \mathrm{z}-215 \rightarrow 169$

Fig. 2. The chromatograms of blank plasma(A) and plasma with methyldopa in the concentration of $0.02 \mu \mathrm{g} / \mathrm{ml}$ (LLOQ) (B)
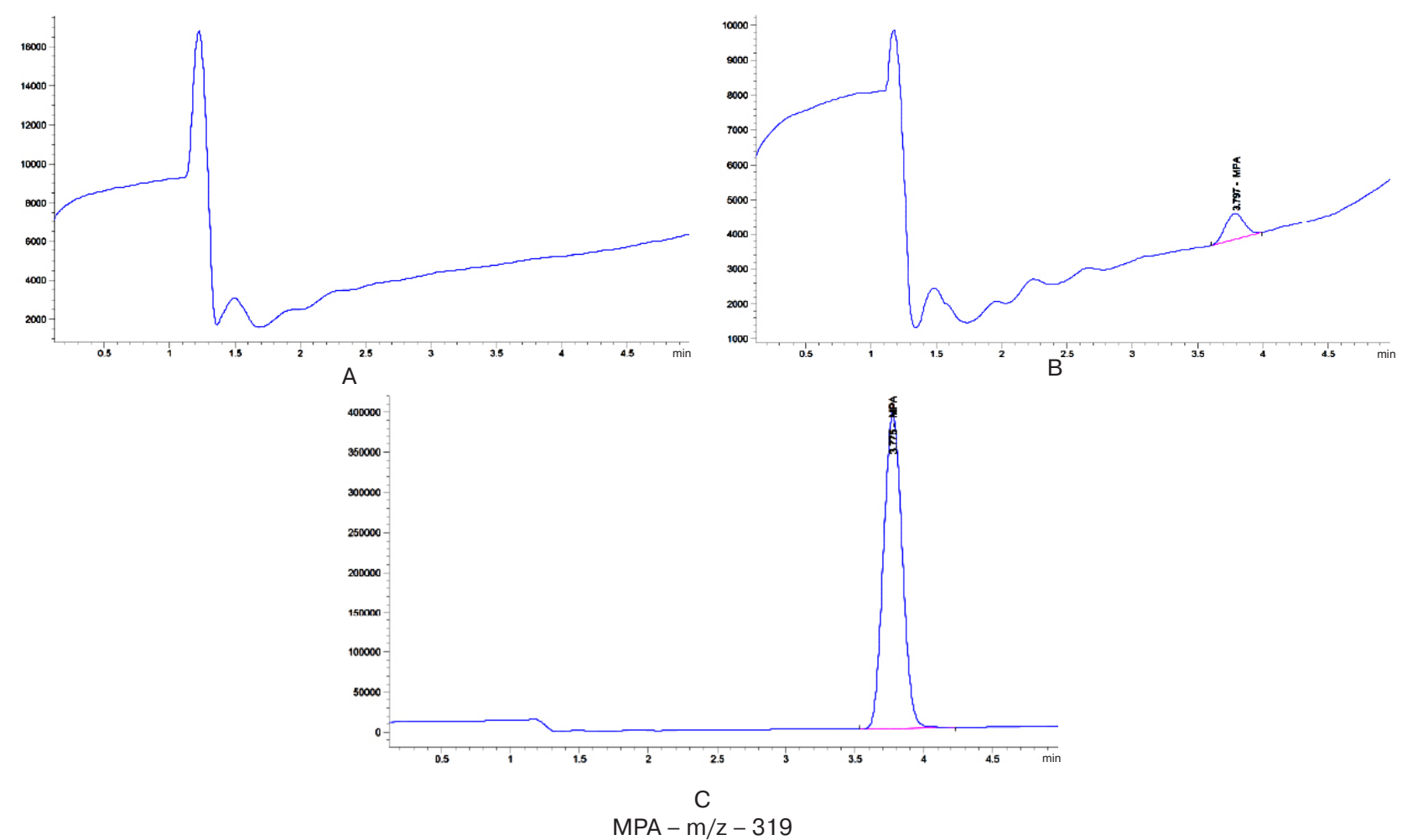

Fig. 3. The chromatograms of blank plasma (A) and plasma with MPA in the concentration of $0.05 \mu \mathrm{g} / \mathrm{ml}$ (LLOQ)

(B) and $30.00 \mu \mathrm{g} / \mathrm{ml}(\mathrm{C})$

Conclusions. Thus, development the method for bioassay of potentially unstable compounds, such as phenolic substances, need to be started with the analysis and evaluation of structural features base on literature data. It is also necessary to pay attention information about the drug and similar structure substances. The selection of storage conditions should begin, with selection of anticoagulant based on the study of short-term stability and freeze/thaw stability. If an unsatisfactory result was obtained, the combination of anticoagulant and antioxidant solution, the concentration of the solution and volume ratio «biological fluid/antioxidant solution» should be investigated. The validation of the method should be started using anticoagulant and antioxidant after the selection (Fig. 4). 


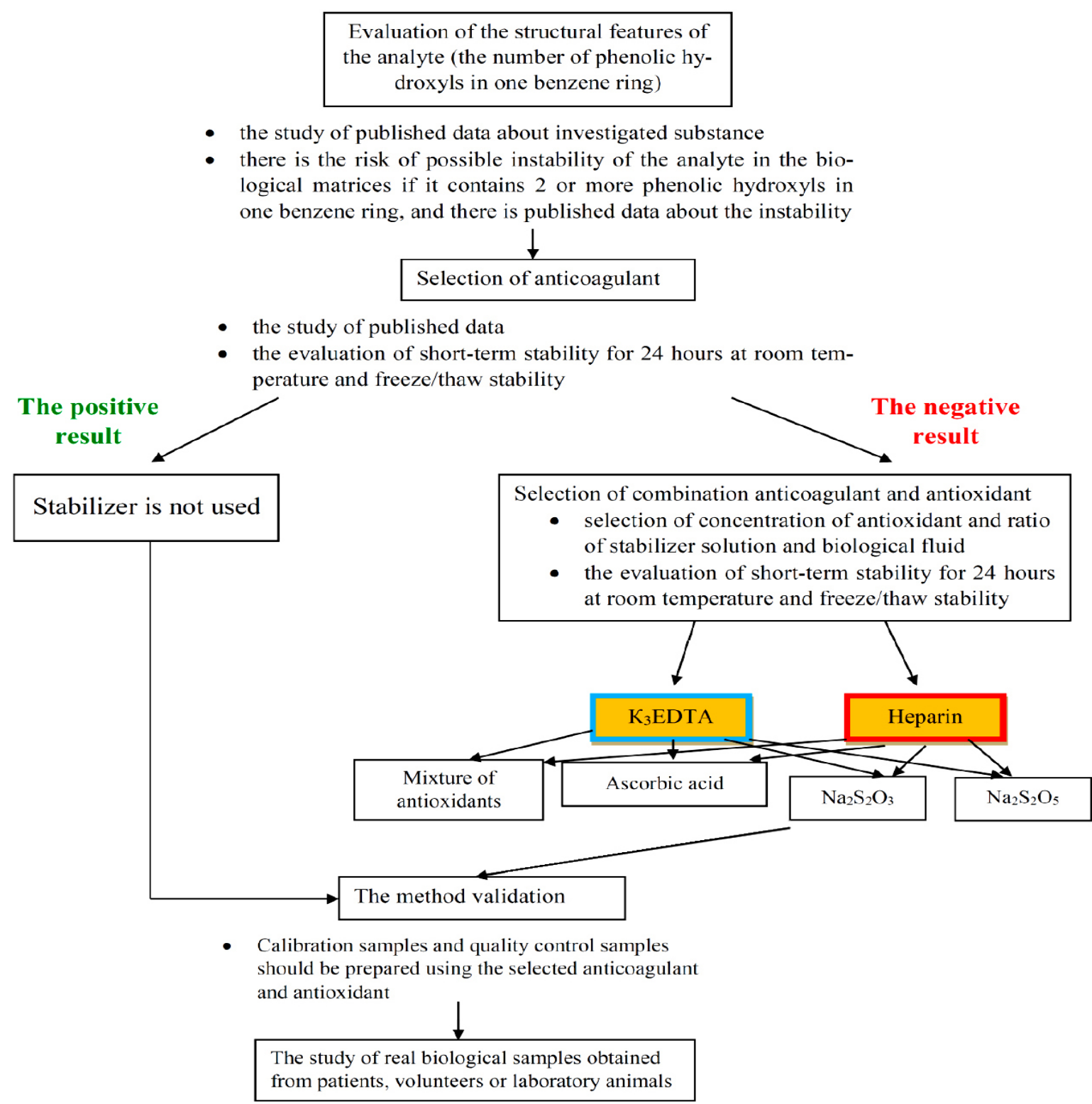

Fig. 4. Approaches to development of bioanalytical method for quantify of drugs containing phenolic hydroxylenes

The method of quantitative determination of $M D$ in plasma was applied in the bioequivalence study of the tablet form in a dosage of $200 \mathrm{mg}$. The method of quantification of mycophenolic acid was used for pharmaco-

\section{References}

1. On the Approval of the Rules for Conducting Bioequivalence Studies of Medicinal Products within the Eurasian Economic Union: Decision of the Council of the Eurasian Economic Commission of November 3, 2016. № 85.

2. Tukavkina N. A., ed. Organic chemistry. Book 1: Basic course. Moscow: Drofa, 2003.

3. Mironov A. N., ed. Manual on expertise of medicines. V. I. Moscow: Grif i K, 2013.

4. Khokhlov A. L., Shitov L. N., Dzhurko Y. A. [et al.] Quantitative determination of mycophenolic acid in human plasma by liquid chromatography - tandem mass spectrometry. Pharm. Chem. J. 2017; 51(6): 58-61.

5. Benoit-Biancamano M.-O., Caron P., Levesque E. [et al.] Sensitive high-performance liquid chromatography-tandem massspectrometry method for quantitative analysis of mycophenolic acid and its glucuronide metabolites in human plasma and urine. J. Chromatogr B. 2007; 858: 159-167. doi: 10.1016/j.jchromb.2007.08.023

6. Brandhorst G., Streit F., Goetze S. [et al.] Quantification by Liquid Chromatography Tandem Mass Spectrometry of Mycophenolic Acid and Its Phenol and Acyl Glucuro- kinetic study of sodium mycophenolate in rats, and also was verified using the previously published HPLC-MS/ MS method.

nide Metabolites Clin Chem 2006:52(10):1962-1964. doi: 10.1373/clinchem.2006.074336

7. Buchwald A., Winkler K., Epting T. [et al.] Validation of an LC-MS/MS method to determine five immunosuppressants with deuterated internal standards including MPA. BMC Clin Pharm 2012:12:1-11 doi: 10.1186/14726904-12-2

8. Delavenne X., Juthier L., Pons B. [et al.] UPLC-MS/ MS method for quantification of mycophenolic acid and metabolites in human plasma: Application to pharmacokinetic study. Clin. Chim. Act. 2011;412:59-65. doi: 10.1016/j.cca.2010.09.041

9. Elbarty F. A., Shoke A. S. Liquid chromatographic determination of mycophenolic acid and its metabolites in human kidney transplant plasma: Pharmacokinetic application. J. Chromatogr. B. 2007;859:276-281. doi: 10.1016/j.jchromb.2007.09.036

10. Guideline on validation of bioanalytical methods (draft): European Medicines Agency, Committee for medicinal products for human use, 2013

11. Heinig K., Bucheli F., Hartenbach R. [et al.] Determination of mycophenolic acid and its phenyl 
glucuronide in human plasma, ultrafiltrate, blood, DBS and dried plasma spots. Bioanal. 2010;8(2):14231435. doi: $10.4155 /$ bio. 10.99

12. Li W., Zhang J., Tse F. L. S. Handbook of LC-MS Bioanalysis. New Jersey: Jonh Wiley and Sons, 2013

13. Maddela R., Pilli N. R., Maddela S. A novel and Rapid LCMS/MS assay for the Determination of Mycophenolate and Mycophenolic Acid in Human Plasma. J. Young Pharm. 2017; 9 (1):107-114. doi: 10.5530/jyp.2017.9.20

14. Oliveira C. H., Barrientos-Astigarraga R. E., Sucupira M. [et al.] Quantification of methyldopa in human plasma by high-performance liquid chromatographyelectrospray tandem mass spectrometry. Application to a bioequivalence study. J. Chromatogr. B. 2002;768(2): 341-348. doi: 10.1016/S1570-0232(01)00612-2

15. Rebollo N., Calvo M. V., Martin-Saurez A. [et al.] Modification of the EMIT immunoassay for the measurement of unbound mycophenolic acid in plasma. Clin. Biochem. 2011;44:260-263. doi: 10.1016/j. clinbiochem.2010.09.025

16. Róna K., Ary K., Renczes G. [et al.] Comparative Bioavailability of Alpha-Methyldopa normal and film tablet formulations after single oral administration in healthy volunteers. Eur. J. Drug Metab. and Pharmacok. 2001:26(1-2):25-30.

17. Valizadeh H., Nemati M., Hallaj-Nezhadi S. [et al.] Single dose bioequivalence study of a-methyldopa tablet formulations using a modified HPLC method. Arzn 2010;60(10):607-611. doi: 10.1055/s-0031-1296333

18. Van de Merbel N. C., Hendriks G., Imbos R. [et al.] Quantitative determination of free and total dopamine in human plasma by LC-MS/MS: the importance of sample preparation. Bioanal. 2011;17(3):1949-1961. doi: 10.4155/bio.11.170

19. Vlase L., Mihu D., Popa D.-S. Determination of methyldopa in human plasma by LC/MS-MS for therapeutic drug monitoring. Stud. Univ. Babes-Bolyai Chem. 2013;58(1):31-41.

20. Upadhuaya V., Trivedy V., Shah G. [et al.] Determination of mycophenolic acid in human plasma by ultra performance liquid chromatography tandem mass spectrometry. J. Pharm. Anal. 2014;4(3):205-216. doi: 10.1016/j.jpha.2013.06.001

21. Wang L., Qiang W., Li Y. [et al.] A novel freeze-dried storage and preparation method for the determination of mycophenolic acid in plasma by high-performance liquid chromatography. Biomed. Chromatogr. 2017;31(5):327. doi: $10.1002 /$ bmc.3958

22. Wiesen M. H. J., Farowski F., Feldkötter M. [et al.] Liquid chromatography-tandem mass spectrometry method for the quantification of mycophenolic acid and its phenolic glucuronide in saliva and plasma using a standardized saliva collection device. J. Chromatogr. A. 2012;1241:52-59. doi: 10.1016/j.chroma.2012.04.008

\title{
About authors:
}

Khokhlov Alexander Leonidovich, DMSc, Professor, Corresponding Member of The Russian Scientific Academy; Head of the Department of Clinical Pharmacology; tel.: +79106631155; e-mail: al460935@yandex.ru

Yaichkov Ilya Igorevich, Post-graduate student of the Department of Clinical Pharmacology, junior scientific worker of Center of transfer of pharmaceutical technologies named after M. V. Dorogov; tel.: + 79109777498; e-mail: ilya_1993_08@mail.ru Dzhurko Yuriy Alexandrovich, CPhSc, Senior analyst; tel.: +79109759248; e-mail: y.dzhurko@qayar.ru

Shitov Leonid Nikolaevich, CBSc, Head of bioanalytical laboratory, Assistant of the Department of Polyclinical Therapy and Clinical Laboratory Diagnostic; tel.: +79106653530; e-mail: schitov@inbox.ru

\section{INTERRELATION OF ENDOTHELIAL NITRIC OXIDE SYNTHASE ACTIVITY IN TISSUES OF THE STOMACH AND MAGNESIUM BALANCE IN THE PERIOD OF EROSIVE-ULCERATIVE ACID-INDUCED LESION DEVELOPMENT IN RATS WITH DIFFERENT RESISTANCE TO STRESS}

Rogova L. N., Povetkina V. N.

Volgograd State Medical University, Russian Federation

\section{ВЗАИМОСВЯЗЬ АКТИВНОСТИ ЭНАОТЕАИААЬНОЙ НИТРОКСИАСИНТАЗЫ В ТКАНЯХ ЖЕАУАКА И МАГНИЕВОГО БАААНСА В ПЕРИОА ФОРМИРОВАНИЯ ЭРОЗИВНО-ЯЗВЕННОГО АЕФЕКТА АЦЕТАТНОЙ ПРИРОАЫ У КРЫС С РАЗНОЙ УСТОЙЧИВОСТЬЮ К СТРЕССУ}

\author{
^. Н. Рогова, В. Н. Поветкина
}

\section{ВолгограАский госуАарственный МеАицинский университет, Российская ФеАерация}

Acetate stomach ulcer was experimentally modeled in stress resistant and stress nonresistant rats for immunohistochemical identifying a specific number and expression intensity of eNOS-positive cells and determination of the magnesium level in biological media. The content of intra-erythrocyte magnesium in reaction with titanium yellow was reduced in rats with different resistance to stress in low eNOS activity in the gastric mucosa, in the muscular layer in stress nonresistant animals and almost complete absence of antigen-positive cells in the submucosa. A positive correlation was found between the level of intra-erythrocyte magnesium and the specific number of eNOS-positive cells in the gastric mucosa in both groups of animals and also between expression intensity in the submucosa of stress nonresistant rats. A relationship was established between the magnesium content, specific number and expression intensity of eNOS in stress nonresistant rats in the stomach submucosa. 